九州大学学術情報リポジトリ

Kyushu University Institutional Repository

\title{
Inactivation of Bacillus Spores Suspended in Physiological Salt Solution, Potage and Ketchup by the Combination of Moderate Heat and Low Hydrostatic Pressure
}

Md. Shahidul Islam

Laboratory of Food Process Engineering, Division of Food Biotechnology, Department of Bioscience and Biotechnology, Graduate school of Bioresoruce and Bioenvironmental Sciences, Kyushu University

\section{Inoue, Ayaka}

Laboratory of Food Process Engineering, Division of Food Biotechnology, Department of Bioscience and Biotechnology, Faculaty of Agriculture, Kyushu University

Igura, Noriyuki

Laboratory of Food Process Engineering, Division of Food Biotechnology, Department of Bioscience and Biotechnology, Faculaty of Agriculture, Kyushu University

Shimoda, Mitsuya

Laboratory of Food Process Engineering, Division of Food Biotechnology, Department of Bioscience and Biotechnology, Faculaty of Agriculture, Kyushu University

他

https://doi.org/10.5109/4537

出版情報：九州大学大学院農学研究院紀要. 48 (1/2)，pp.143-151，2003-10-01. Faculty of Agriculture, Kyushu University

バージョン：

権利関係: 


\title{
Inactivation of Bacillus Spores Suspended in Physiological Salt Solution, Potage and Ketchup by the Combination of Moderate Heat and Low Hydrostatic Pressure
}

\section{Md. Shahidul ISLAM*, Ayaka INOUE**, Noriyuki IGURA, Tatsuo KATO, Mitsuya SHIMODA and Isao HAYAKAWA ${ }^{\dagger}$}

\author{
Laboratory of Food Process Engineering, Division of Food Biotechnology, \\ Department of Bioscience and Biotechnology, Faculty of Agriculture, \\ Kyushu University, Fukuoka 812-8581, Japan \\ (Received June 30, 2003 and accepted July 15, 2003)
}

\begin{abstract}
The inactivation effect of combined treatment of moderate heat and low hydrostatic pressure (MHP) of B. subtilis, B. coagulans and B. stearothermophilus spores suspended in physiological salt solution and in food materials such as potage and ketchup was investigated. $B$. coagulans spores were more heat and pressure resistant compared to other spores tested in this experiment. There were 4-8 log cycle reductions of Bacillus spores in potage and physiological salt solution during MHP treatment at $85^{\circ} \mathrm{C}$ for $12 \mathrm{~h}$, and long time heat treatment could not kill any $B$. coagulans and $B$. stearothermophilus spores under the same treatment temperature and time. $B$. subtilis and $B$. stearothermophilus spores were completely inactivated at $65^{\circ} \mathrm{C}$ for $3 \mathrm{~h}$ and $85^{\circ} \mathrm{C}$ for $6 \mathrm{~h}$, respectively, during MHP treatment in physiological salt solution and potage. In ketchup, all Bacillus spores are highly sensitive in both MHP and heat treatments. B. subtilis spores were completely inactivated in ketchup at $75^{\circ} \mathrm{C}$ and other two strains were inactivated at $85^{\circ} \mathrm{C}$. These results indicate that MHP treatment could be utilized in low acid food to achieve high sporicidal activity and used as an effective alternative to high temperature retort processing or ultra high pressurization.
\end{abstract}

\section{INTRODUCTION}

Consumers demand high quality, minimally processed foods with fresh characteristics and no additives. A novel food preservation method receiving wide attention is high pressure processing wherein the food is treated at elevated pressures of $100-1000 \mathrm{MPa}$ for a specified temperature and time. The destruction of microorganisms by high pressure was reported 100 years ago (Hite, 1899). From many studies, it was indicated that the hydrostatic pressure can inactivate microorganisms without altering the flavor and nutrient components of foods (Cheftle, 1992). At present retort processing, which used high temperature such as $121-135^{\circ} \mathrm{C}$ for $20 \mathrm{~min}$ holding time followed by $20 \mathrm{~min}$ cooling, is employed to eliminate bacterial spores in food, but the high temperature necessary for inactivation causes losses in nutrients, produces burnt flavor and allergic components (Codina et al., 1998; Chung \& Champagne, 1999).

* Laboratory of Food Process Engineering, Division of Food Biotechnology, Department of Bioscience and Biotechnology, Graduate school of Bioresource and Bioenvironmental Sciences, Kyushu University

** Program of Food Science and Technology, Course of Applied Biological Science, Department of Bioresource and Bioenviornment, School of Agriculture, Kyushu University

+ Corresponding Author (E-mail: hayakawa@agr.kyushu-u.ac.jp) 
In high pressure sterilization, bacterial spores were more resistance than vegetative bacteria (Timson \& Short, 1965; Cheftle, 1992), surviving up to $1200 \mathrm{MPa}$ (Larson et al., 1918; Johnson \& Zobell, 1949; Timson \& Short, 1965; Sale et al., 1970). Hence, it has been suggested that bacterial spores are poorly inactivated by the hydrostatic pressure treatment at room temperature (Sonoike, 1997). On the other hand, combination with heat was effective mean to increase the inactivation of bacterial spores (Gould, 1973; Mallidis \& Drizou, 1991; Roberts \& Hoover, 1996). Whereas, pressure $>600 \mathrm{MPa}$ combining with mild or moderate heat was required to inactivate all spores (Hayakawa et al., 1994a, b; Mills et al., 1998). According to the material strength, it is possible to make pressure equipment with a vessel size over 10 ton under reasonable cost if operating pressure is $\leq 100 \mathrm{MPa}$. On the contrary, it can be only make very small size pressure vessel $(<100 \mathrm{~kg}$ ) if the operating pressure is $2600 \mathrm{MPa}$. Considering these facts, in our laboratory several attempts have been made to reduce the pressure by combining heat treatment (Furukawa \& Hayakawa, 2000, 2001 Furukawa et al., 2001). Furukawa and Hayakawa (2001) suggested that low hydrostatic pressure from 60 to $100 \mathrm{MPa}$ is highly effective in sterilizing $B$. stearothermophilus spores in combination with long time heating at $75-95^{\circ} \mathrm{C}$. B. stearothermophilus spores are the most heat-tolerant species among aerobic spore-forming bacteria. This microorganism is often used as a biological indicator to evaluate sterilization processes because of its high heat resistance (López et $a l .$, 1997). We also examined $B$. subtilis spores as it is most popular spore-forming bacteria among foods in neutral $\mathrm{pH}$, and $B$. coagulans spores as it is pressure resistance and relatively high heat resistance at acidic pH (Palop et al., 1999a). Mallidis et al. (1990) demonstrated that $B$. coagulans spores was able to germinate and grow at $\mathrm{pH}$ values as low as 4 , and are the microorganisms most frequently isolated from spoiled canned vegetables acidified to $\mathrm{pH}$ values between 4 and 4.5 .

In the present paper, we investigated the inactivation effect of combined treatment of moderate heat and low hydrostatic pressure for long time on the inactivation of $B$. subtilis, B. coagulans and $B$. stearothermophilus spores suspended in physiological salt solution, potage and ketchup.

\section{MATERIALS AND METHODS}

\section{Bacteria}

The bacteria used were Bacillus subtilis IFO 13722, Bacillus coagulans IFO 12583 and Bacillus stearothermophilus IFO 12550, obtained from the Institute for Fermentation, Osaka (Osaka, Japan).

\section{Physiological salt solution, Potage and Ketchup}

Sodium chloride (Nacalai Tesque, Inc., Kyoto, Japan) was used to prepare physiological salt solution. Potage ( $\mathrm{pH} 7$, Nagoya Seiraku Co. Ltd., Japan) and tomato ketchup (pH 4 , Kagome Co. Inc., Tokyo, Japan) were obtained from the local market and refrigerate at $4^{\circ} \mathrm{C}$ until use.

\section{Media and culture conditions}

The $\log$-phase cultures of $B$. subtilis, B. coagulans and B. stearothermophilus 
grown in nutrient broth (Eiken Chemical Co., Ltd., Tokyo, Japan) were transferred to soil-infusion agar-plates (Berry \& Brandshaw, 1980), which consisted of nutrient agar (Eiken Chemical Co. Ltd.) plus a soil extract. The plates for B. subtilis and B. coagulans were incubated at $37^{\circ} \mathrm{C}$, and $B$. stearothermophilus was incubated at $55^{\circ} \mathrm{C}$ for 10days.

\section{Preparation of spore suspension}

Spores were collected by flooding the surface of the culture with sterile distilled water, and then scraped the surface with a sterile microscopic glass slide. After collecting, the spores were washed three times by centrifugation at $7000 \times g$ for $10 \mathrm{~min}$ in sterile distilled water, resuspended in sterile physiological salt solution, potage and ketchup to a concentration of $10^{7}-10^{8} \mathrm{CFU} / \mathrm{ml}$ for $B$. subtilis and $10^{6}-10^{7} \mathrm{CFU} / \mathrm{ml}$ for $B$. coagulans and $B$. stearothermophilus. One $\mathrm{ml}$ of spore suspension was added to the $9 \mathrm{ml}$ of potage or ketchup to prepare the spore suspension. The spore solution was sealed in a germ-free tube (volume-1.5 ml, Greiner Labortechnik Co., Ltd., Germany) and kept at $4^{\circ} \mathrm{C}$ prior to heat and MHP treatments.

\section{Heat treatment}

Bacillus spores in sealed tubes were heated in a water bath at 65,75 , and $85^{\circ} \mathrm{C}$ for 3 , 6,9 and $12 \mathrm{~h}$. After heat treatment the tubes were cooled immediately in crushed ice and the spores were subjected to viable count immediately.

\section{MHP treatment}

Spores in sealed tubes were applied to hydrostatic pressure treatment at $100 \mathrm{MPa}$ for the same temperature and time as heat treatment using a prototype pressurization apparatus (Yamamoto Suiatsu Kogyosho Co., Ltd., Osaka, Japan) in a cylindrical pressure chamber (inside volume: $8 \mathrm{~L}$ ). Schematic diagram of prototype pressurization apparatus was shown in Fig. 1. The pressurization rate was $20 \mathrm{MPa} / \mathrm{min}$, and decompression time from $100 \mathrm{MPa}$ to $0.1 \mathrm{MPa}$ was less than $20 \mathrm{sec}$. Adiabatic heat generated during pressurization was about $3^{\circ} \mathrm{C} / 100 \mathrm{MPa}$. The temperature variation was regulated to $\pm 2{ }^{\circ} \mathrm{C}$ by a voltage controller (type: S-130, Yamabishi Co. Ltd., Tokyo, Japan). Treatment temperature was monitored by a digital temperature controller (type: SR-62, Shimaden Co. Ltd., Tokyo, Japan) with a thermocouple placed inside the top of pressure chamber. Deionized water was used as the pressure medium. After MHP treatment spore survivors were enumerated by the same procedure of heat treatment.

\section{Measurement of survivors}

Survivors after pressurization and heat treatment were estimated by the viable count method using nutrient agar (Eiken Chemical Co. Ltd.). The plates for B. subtilis and $B$. coagulans were incubated at $37^{\circ} \mathrm{C}$ for $24 \mathrm{~h}$ and $72 \mathrm{~h}$ respectively, and $B$. stearothermophilus were incubated at $55^{\circ} \mathrm{C}$ for $48 \mathrm{~h}$ and then the colonies were enumerated.

\section{Statistical Analysis}

All experiments were carried out at least in three replicates and the data were presented by the standard deviations of the averages for the number of experiments repeated. 


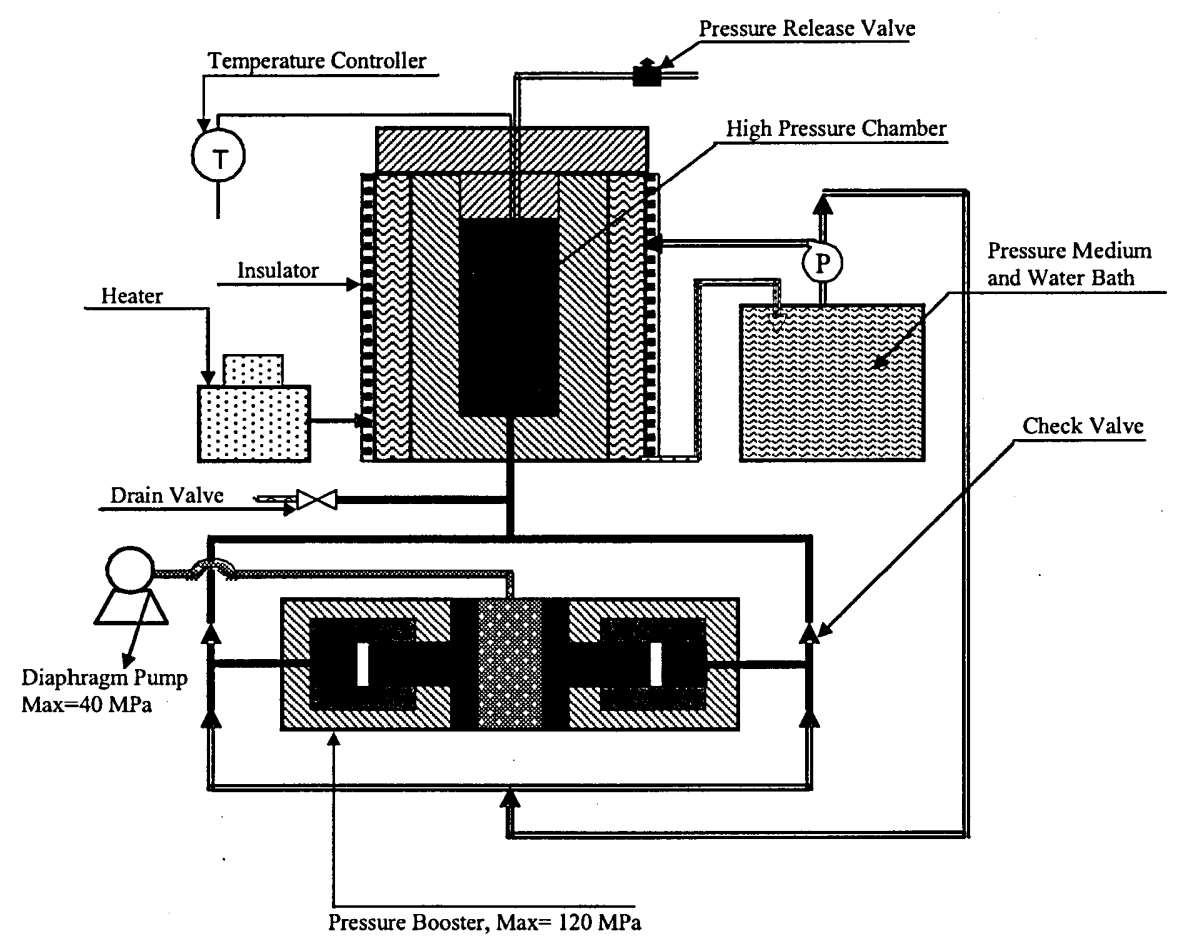

Fig. 1. Schematic diagram of prototype MHP treatment apparatus with double booster.

\section{RESULTS AND DISCUSSION}

The effect of treatment temperature and time on the inactivation of $B$. subtilis spores in physiological salt solution, potage and ketchup are shown in Fig. 2. In MHP treatment, $B$. subtilis spores were completely inactivated in physiological salt solution and potage at $65^{\circ} \mathrm{C}$ for $3 \mathrm{~h}$, whereas the spores were inactivated by only 1-log cycle in potage and 1.5-log cycles in physiological salt solution during heat treatment at $65^{\circ} \mathrm{C}$ for $12 \mathrm{~h}$. On the other hand, MHP and heat treatments showed 4-log and 6-log reductions of the spores in ketchup at $65^{\circ} \mathrm{C}$ for $12 \mathrm{~h}$, respectively.

The inactivation behaviors of $B$. coagulans spores in physiological salt solution and food materials are shown in Fig. 3. The number of spores was not decreased after heat treatments at $85^{\circ} \mathrm{C}$ for treatment time up to $12 \mathrm{~h}$ in both physiological salt solution and potage. Considerably a 4-log reduction was achieved in the same menstruum during MHP treatment. In ketchup, heat treatments showed a $3.5-\log$ reduction at $75^{\circ} \mathrm{C}$ for $12 \mathrm{~h}$, whereas MHP treatment showed only a $1-\log$ reduction at the same temperature. There are 6.5-log reductions in heat and MHP treatment at $85^{\circ} \mathrm{C}$ for $12 \mathrm{~h}$, although $3-9 \mathrm{~h}$ heat treatments are more pronounced than MHP treatment and this behavior is similar to $B$. subtilis spores. 


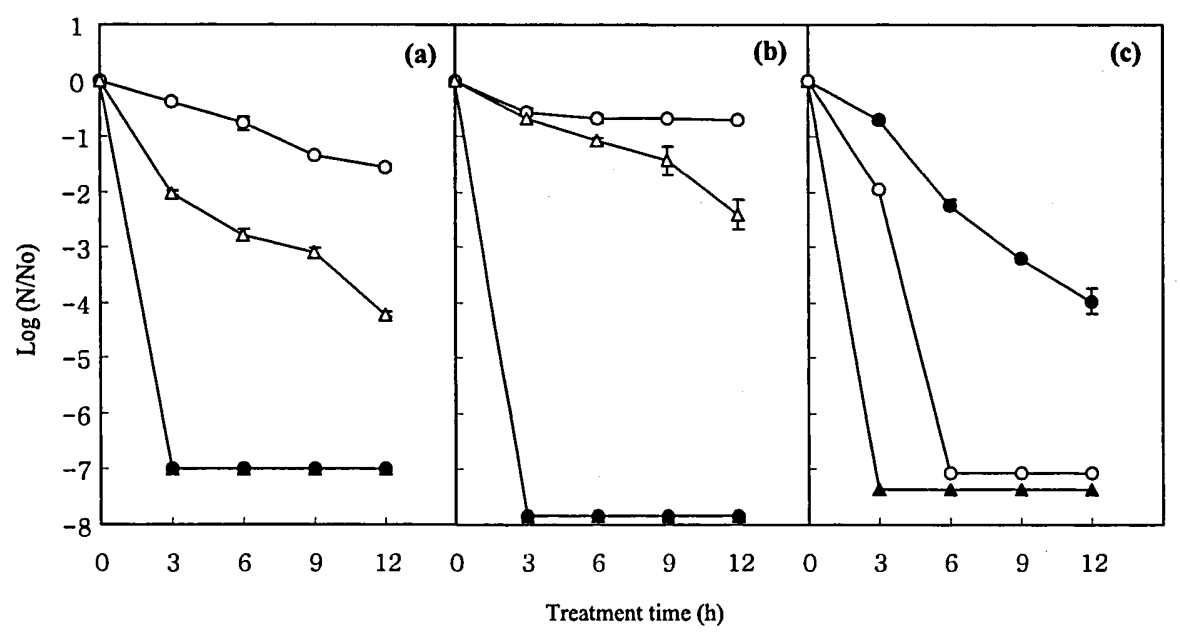

Fig. 2. The inactivation behaviors of Bacillus subtilis spores subjected to the MHP treatment (closed symbols) and heat treatment (open symbols) at $65^{\circ} \mathrm{C}(\boldsymbol{O}, \mathrm{O})$ and $75^{\circ} \mathrm{C}(\boldsymbol{\Delta}, \Delta)$ in (a) physiological salt solution, (b) potage (pH 7) and (c) ketchup (pH 4). N; Colony counts after the treatment (CFU/ml) and No; Initial colony counts (CFU/ml).

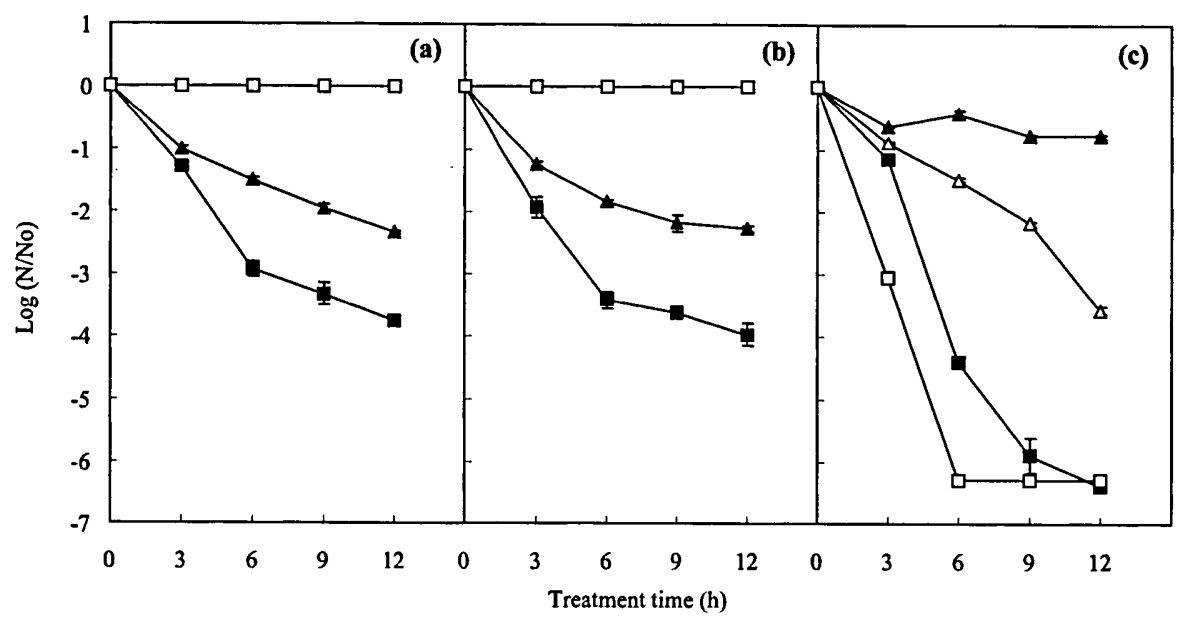

Fig. 3. The inactivation behaviors of Bacillus coagulans spores subjected to the MHP treatment (closed symbols) and heat treatment (open symbols) at $75^{\circ} \mathrm{C}(\boldsymbol{\Delta}, \triangle)$ and $85^{\circ} \mathrm{C}$ $(\boldsymbol{\square}, \square)$ in (a) physiological salt solution, (b) potage (pH 7) and (c) ketchup (pH 4).

B. stearothermophilus spores in potage have no sterilization effect during heat treatment at $85^{\circ} \mathrm{C}$ for $12 \mathrm{~h}$, and in physiological salt solution only have 1.5-log reductions under the same treatment temperature and time (Fig. 4). Whereas, 6-log reductions of $B$. stearothermophilus spores have achieved in physiological salt solution and potage 


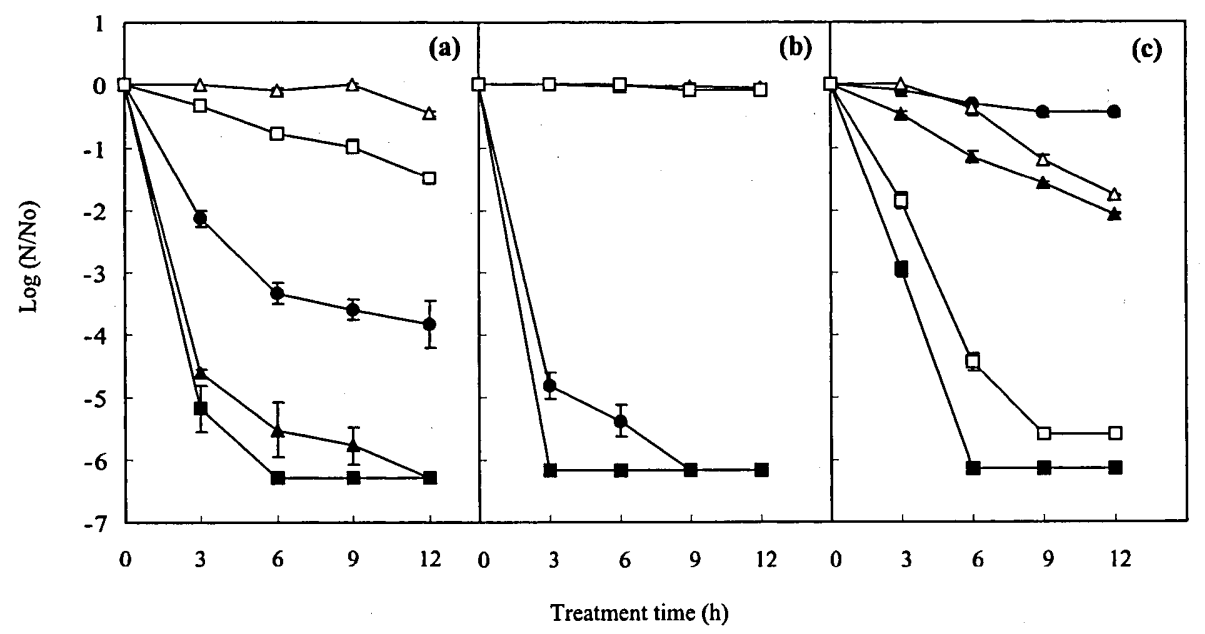

Fig. 4. The inactivation behaviors of Bacillus stearothermophilus spores subjected to the MHP treatment (closed symbols) and heat treatment (open symbols) at $65^{\circ} \mathrm{C}(\mathbf{O}, \mathrm{O}), 75^{\circ} \mathrm{C}$ $(\boldsymbol{A}, \triangle)$ and $85^{\circ} \mathrm{C}(\boldsymbol{\square}, \square)$ in (a) physiological salt solution, (b) potage (pH 7) and (c) ketchup ( $\mathrm{pH} 4)$.

during MHP treatment at $85^{\circ} \mathrm{C}$ for $6 \mathrm{~h}$ and $3 \mathrm{~h}$, respectively. Result shows the spores are more resistant in potage than physiological salt solution during heat treatment, and in MHP treatment the spores are more sensitive in potage than physiological salt solution. The spores were sensitive in ketchup to heat and MHP treatment, that was 5.5-log reductions in heat treatment and 6-log reductions in MHP treatment at $85^{\circ} \mathrm{C}$ for $9-12 \mathrm{~h}$ (Fig. 4).

Furukawa and Hayakawa (2001) have studied the combined effect of low hydrostatic pressure and heat treatments on the inactivation of $B$. stearothermophilus spores in standard buffer solutions. Results showed that $100 \mathrm{MPa}, 80^{\circ} \mathrm{C}, 12 \mathrm{~h}$ can reduce $5.5-\log$ of spores and the results are similar to our data of potage and physiological salt solution (Fig. 4).

Microorganisms usually have their maximum heat resistance at $\mathrm{pH}$ values close to neutrality. Condon and Sala (1992) demonstrated that the heat resistance of $B$. subtilis spores in foods is mostly determined by the $\mathrm{pH}$ of food. Our data shows that Bacillus spores are more heat resistant in potage $(\mathrm{pH} \mathrm{7)}$ and then in physiological salt solution (pH 7) and this is the agreement with the early studies (Condon \& Sala, 1992) showing that the spores are more heat resistance in a neutral $\mathrm{pH}$.

Results show higher inactivation in ketchup both in heat and MHP treatment. This may be due to the fact that in high acid the minerals of spores became demineralized and change to H-spore. Some researchers demonstrated that demineralization of spores markedly reduces heat resistance of bacterial spores (Marquis et al., 1981; Bender \& Marquis, 1985; Palop, et al.,1999b).

Wuytack et al., (2000) have shown that Bacillus spores are germinated at $100 \mathrm{MPa}$ 
pressurization in the presence of nutrient germinant L-alanine. Germinant (amino acid content such as L-alanin) has an influence in germination and inactivation of potage during MHP treatment. Our results showed that all Bacillus spores had higher inactivation in potage during MHP treatment compared to heat treatment. This indicates that amino acid content in potage initiate germination of spores during pressurization.

Our investigation showed that $B$. coagulans spores are more resistant in physiological salt solution, potage and ketchup compared to other two strains of bacterial spores used in this experiment. Heat resistance of $B$. coagulans spores has been extensively studied in tomato. As far as we know, there are no data available in the literature regarding the behavior of $B$. coagulans spores in the MHP treatment temperature around $65-85^{\circ} \mathrm{C}$ for long time, to which our results can be compared. Although Palop et al., (1999a) demonstrated that the acidification of the heating menstruum leads to a decrease in heat resistance of $B$. coagulans spores, the heat resistance being also influenced by the composition of the medium and the treatment temperature. Condon and Sala (1992) showed that apart from $\mathrm{pH}$, the composition of heating menstruum (buffer, tomato paste) can also influence the heat resistance of microorganisms.

In pressure treatment, pressure medium (water) compressed $4.1 \%$ of its volume during $100 \mathrm{MPa}$ pressurization at $85^{\circ} \mathrm{C}$ (Kell, 1983). Therefore, spore shape will be also compressed at the same volume. By the combination with moderate heating and long time pressurization, water may penetrate into the spore interior which may weaken of the spore coat. Paidhungat et al. (2002) showed that a pressure of $100 \mathrm{MPa}$ induces spore germination by activating the germinant receptors. Thus, spore becomes rupture in MHP treatment with spore germination and long time heating inactivate the germinated spores. Therefore, the inactivation is higher in MHP treatment compared to heat treatment in the low acid food.

The economic feasibility of pressure processing requires that treatment conditions are optimized to achieve the lowest pressure and moderate heat combinations needed to sufficiently eliminate bacterial spores of concern from the foods being treated. Our results showed $100 \mathrm{MPa}$ pressurization could be eliminated bacterial spores sufficiently and low pressure treatment will reduce equipment manufacturing cost and possible to make large pressurization equipment from present engineering technology.

\section{ACKNOWLEDGMENT}

One of the authors (Md. Shahidul Islam) expresses his best gratitude to the Ministry of Education, Culture, Sports, Science and Technology for its scholarship to conduct this research.

\section{REFERENCES}

Bender, G. R. and R. E. Marquis 1985 Spore heat resistance and specific mineralization. Appl. and Environ. Microbiol., 50: 1414-1421

Berry, M. R., Jr. and J. G. Brandshaw 1980 Heating characteristics of condensed cream of celery soup in a steritort: heat penetration and spore count reduction. J. Food Sci., 45: 869-879

Cheftel, J. C. 1992 Effects of high hydrostatic pressure on food constituents: an overview. In "High pressure biotechnology", ed. by C. Balny, R. Hayashi, K. Heremans, and P. Masson, Colloque INSERM/John Libbey and Co., Ltd. London, pp. 195-209 
Chung, S. Y, and E. T. Champagne 1999 Allergenicity of Maillard reaction products from peanut proteins. J. Agr. Food Chem., 47: 5227-5231

Codina, R., A. G. Oehling and R. F. Lockey, 1998 Neoallergrns in heated soybean hull. Int. Archives Allergy and Immunol., 117: 120-125

Condon, S. and F. J. Sala 1992 Heat resistance of Bacillus subtilis in buffer and foods of different $\mathrm{pH}$. J. of Food Prot., 55: 605-608

Furukawa, S. and I. Hayakawa 2000 Investigation of desirable hydrostatic pressure required to sterilize Bacillus stearothermophilus IFO 12550 spores and its sterilization properties in glucose, sodium chloride and ethanol solutions. Food Res. Int., 33: 901-905

Furukawa, S. and I. Hayakawa 2001 Effect of temperature on the inactivation of Bacillus stearothermophilus IFO 12550 spores by low hydrostatic pressure treatment. Biocontrol Sci., 6: 33-36

Furukawa, S., A. Matsuoka, Y. Nakamichi, T. Kato, M. Shimoda, and I. Hayakawa 2001 Inactivation of spores of three Bacillus strains by low hydrostatic (LHP) treatment. J. Fac. Agr., Kyushu Univ., 45: $525-530$

Gould, G. W. 1973 Inactivation of spores in food by combined heat and hydrostatic pressure. Acta. Aliment., 2: 377-383

Hayakawa, I., T. Kanno, M. Tomita and Y. Fujio 1994a Application of high pressure for spore inactivation and protein denaturation. J. Food Sci., 59: 159-163

Hayakawa, I., T. Kanno, K. Yoshiyama, and Y. Fujio 1994b Oscillatory compared with continuous high-pressure sterilization on Bacillus stearothermophilus spores. J Food Sci., 59: 164-167

Hite, B. H. 1899 The effect of pressure in the preservation of milk. Morgantown: West Virginia University of Agriculture Experimental Station, Bulletin, 58: 15-35

Johnson, F. H. and C. E. Zobell 1949 The retardation of thermal disinfection of Bacillus subtilis spores by hydrostatic pressure. J. Bacteriol., 57: 353-358

Kells, G. S. 1983 Thermodynamic and transport properties of fluid water, In "Water-A Comprehensive Treatise, Vol. 1, $4^{\text {th }}$ (ed)", ed. By F. Franks, Plenum Press, New York, pp 363-412

Larson, W. P., T. B. Hartzell and H. S. Diehl 1918 The effect of high pressure on bacteria. J. Infect. Dise, 22: 271-279

López, M., I. González, M. Mazas, J. González, R. Martin and A. Bernardo 1997 Influence of recovery conditions on apparent resistance of Bacillus stearothermophilus spores. Int. J. Food Sci. Tech. , 32: 305-311

Mallidis, C. G. and D. Drizou 1991 Effect of simultaneous application of heat and pressure on the survival of bacterial spores. J. Appl. Bacteriol., 71: 285-288

Mallidis, C. G., P. Frantzeskakis, G. Balatsouras and C. Katsabotxakis 1990 Thermal treatment of aseptically processed tomato paste. Int. J. Food Sci. Technol., 25: 442-448

Marquis, R. E., E. L. Carstersen, S. Z. Child and G. R. Bender 1981 Preparation and characterization of various salt forms of Bacillus megaterium spores, In "Sporulation and germination", ed. by H. S. Levinson, A. L. Sonenshein and D. J. Tipper, American Society for Microbiology, Washington, D. C. pp. 266-268

Mills, G., R. Earnshaw, and M. F. Patterson 1998 Effects of high hydrostatic pressure on Clostridium sporogenes spores. Letters in Appl. Microbiol., 26: 227-230

Paidhungat, M., B. Setlow, W. B. Daniels, D. Hoover, E. Papafragkou and P. Setlow, 2002 Mechanisms of induction of germination of Bacillus subtilis spores by high pressure. Appl. and Environ. Microbiol., 68: 3172-3175

Palop, A., J. Raso, R. Pagán, S. Condón and F. J. Sala 1999a Influence of pH on heat resistance of spores of Bacillus coagulans in buffer and homogenized foods. Int. J. of Food Microbiol., 46: 243-249

Palop, A., F. J. Sala and S. Condón 1999b Heat resistance of Native and demineralized spores of Bacillus subtilis sporulated at different temperatures. Appl. and Environ. Microbiol., 65: 1316-1319

Roberts, C. M. and D. G. Hoover 1996 Sensitivity of Bacillus coagulans spores to combinations of high hydrostatic pressure, heat, acidity and nisin. J. Appl. Bacteriol., 81: 363-368

Sale, A. J. H., G. W. Gould and W. A. Hamilton 1970 Inactivation of bacterial spores by hydrostatic pressure. J. Gen. Microbiol., 60: 323-334

Sonoike, K. 1997 High pressure sterilization technology. Subject for the application to food (in Japanese). J. Jap. Soc. for Food Sci. and Tech., 44: 522-530

Timson, W. J. and A. J. Short 1965 Resistance of microorganisms to hydrostatic pressure. Biotechnology 
and Bioengineering, 7: 139-159

Wuytack, E. Y., J. Soons, F. Poschet and C. W. Michiels 2000 Comparative study of pressure and nutrient-induced germination of Bacillus subtilis spores. Appl. and Environ. Microbiol., 66: 257-261 